J. Perinat. Med. $11(1983) 121$

\title{
A comparative study of the clinical use of four placental proteins in the third trimester
}

\author{
B. C. Obiekwe, T. Chard
}

Departments of Reproductive Physiology and Obstetrics and Gynaecology, St. Barholomew's Hospital Medical College and The London Hospital Medical College, London UK

\section{Introduction}

The human placenta secretes a variety of protein hormones and steroids into the maternal circulation; measurement of these is widely used as a diagnostic marker of fetal wellbeing in both early and late pregnancy $[3,9]$. The recent identification of a number of new specific placental proteins with no known function [10] has provoked considerable interest in their possible clinical application in pregnancy. Notable among these are pregnancy specific $\beta_{1}$ glycoprotein (SP1) and placental protein 5 (PP5). Maternal serum levels of SP1 are related to the delivered weight of the infant and can be used to identify intrauterine growth retardation $[4,7,14,23,25,26]$. Placental protein 5 is much less efficient in this respect [17] but has great potential interest because of its possible association with the coagulation system $[16,20]$ and the fact that elevated levels may be associated with pre-eclampsia [11], placental abruption [21] and premature labor [22]. The present study was designed to compare the clinical usefulness of four placental proteins (hCG, hPL, SP1 and PP5) in the prediction of fetal status at delivery (weight and presence or absence of fetal distress).

\section{Materials and methods}

Single blood samples were taken from 527 unselected women with a singleton pregnancy between

\section{Curriculum vitae}

BENJAMIN C. OBIEKWE was born in 1945. He studied medicine at the Welsh National School of Medicine in Cardiff and qualified in 1970. He is a specialist obstetrician and gynaecologist and for the last five years has worked in the Departments of Obstetrics and Gynaecology, and Reproductive Physiology at St. Bartholomew's Hospital Medical College in London.

36 and 40 weeks gestation. The group included 27 patients with mild to moderate pre-eclampsia (diastolic blood pressure $90-100 \mathrm{~mm} \mathrm{Hg}$ with or without proteinuria), seven with antepartum hemorrhage and five who delivered a stillborn child; the latter were excluded from the overall analysis. Serum was stored at $-20^{\circ} \mathrm{C}$ until assay. The measurement of hCG, hPL, SP1 and PP5 was performed by radioimmunoassay as described previously $[6,7,12,16]$. The results were analysed by calculation of means and standard deviations after logarithmic transformation of the data: The latter were used for comparison of sub-population by Student's t-test. The data were divided into centiles and the sensitivity, predictive value and specificity of each test were calculated in respect of the diagnosis of intrauterine growth retardation 
Tab. I. Maternal circulating levels of hCG, hPL, SP1 and PP5 at 36-40 weeks gestation in the population described ( 522 subjects) and in 27 patients with pre-eclampsia

\begin{tabular}{lllll}
\hline Proteins & $\begin{array}{l}\text { Geo- } \\
\text { metric } \\
\text { mena }\end{array}$ & Median & $\begin{array}{l}10 \text { th } \\
\text { centile }\end{array}$ & $\begin{array}{l}90 \text { th } \\
\text { centile }\end{array}$ \\
& & & \\
\hline
\end{tabular}

\begin{tabular}{lrrrr}
\hline hCG $(\mu \mathrm{g} / \mathrm{l})$ & & & & \\
total population & 105.6 & 108 & 47 & 248 \\
pre-eclampsia & 101.4 & 84 & 40.6 & 286 \\
$\begin{array}{l}\text { hPL }(\mathrm{mg} / \mathrm{l}) \\
\text { total population }\end{array}$ & 6.828 & 7 & 4.8 & 9.7 \\
$\begin{array}{l}\text { pre-eclampsia } \\
\text { SP1 (mg/l) }\end{array}$ & 6.820 & 6.7 & 4.54 & 9.72 \\
$\begin{array}{l}\text { total population } \\
\text { pre-eclampsia }\end{array}$ & 250.1 & 260 & 125 & 470 \\
$\begin{array}{l}\text { PP5 }(\mu \mathrm{g} / \mathrm{l}) \\
\text { total population }\end{array}$ & 228.4 & 245 & 81.6 & 444.5 \\
pre-eclampsia & 52.59 & 55.35 & 34 & 75 \\
\hline
\end{tabular}

(IUGR) and fetal distress. Intrauterine growth retardation was defined as an infant whose birth weight was equal or less than the 10th centile of the whole population in this study $(2740 \mathrm{~g})$. Fetal distress was defined as an abnormal variation of the fetal heart rate using cardiotography (early or late deceleration including tachycardia $>160 / \mathrm{min}$ or bradycardia $<120 / \mathrm{min}$ ) and/or the presence of fresh meconium in the amniotic fluid during labor; neonatal asphyxia was defined as an APGAR score of 6 or less at 1 minute.

\section{Results}

The median levels of hCG, hPL, SP1 and PP5 were stable between 36 and 40 weeks; the mean values of each protein for the total population is shown in Tab. I. There was no difference in the levels of hCG, hPL, Sp1 and PP5 in patients with preeclampsia when compared to the whole population (Tab. I). Only hPL showed a significant association with growth retardation (Tab. II). The sensitivity, predictive value and specificity of all four proteins in the diagnosis of this condition are shown in Tab. III, and again, only hPL showed a sensitivity and predictive value which would be of any clinical significance.

Both hCG and hPL were significantly decreased in subjects whose infants developed fetal distress during labor (Tabs. IV, V). The mean levels of all four proteins were elevated in the group with neonatal asphyxia (Tab. IV) but this was not statistically significant. The mean birthweight of the group with fetal distress alone $(3273 \mathrm{~g})$ did not differ from that in the population as a whole (3303 g).

\section{Discussion}

This is the first study in which maternal serum hCG, hPL, SP1 and PP5 have been examined in the same obstetric population in late pregnancy. The

Tab. II. Maternal circulating levels of hCG, hPL, SP1 and PP5 at 36-40 weeks gestation in 54 subjects with a growth retarded fetus ( $\leqslant 10$ th centile of population range) compared with 468 subjects delivering a fetus of normal weight

\begin{tabular}{|c|c|c|c|c|c|}
\hline Birthweight groups & $\begin{array}{l}\text { Geometric } \\
\text { mean }\end{array}$ & Median & 10th centile & 90th centile & $\begin{array}{l}t \text { value and propability ( } p) \\
\text { of difference }\end{array}$ \\
\hline \multicolumn{6}{|l|}{$\mathrm{hCG}(\mu \mathrm{g} / 1)$} \\
\hline $\begin{array}{l}\text { Birthweight }>10 \text { th centile } \\
\text { Birthweight } \leqslant 10 \text { th centile }\end{array}$ & $\begin{array}{l}107.6 \\
92.07\end{array}$ & $\begin{array}{l}108.5 \\
110\end{array}$ & $\begin{array}{l}48 \\
40.2\end{array}$ & $\begin{array}{l}254.5 \\
200\end{array}$ & $t=1.45(N S)$ \\
\hline $\begin{array}{l}\text { hPL (tmg/l) } \\
\text { Birthweight }>10 \text { th centile } \\
\text { Birthweight } \leqslant 10 \text { th centile }\end{array}$ & $\begin{array}{l}6.947 \\
5.918\end{array}$ & $\begin{array}{l}7.1 \\
5.9\end{array}$ & $\begin{array}{l}5 \\
4.04\end{array}$ & $\begin{array}{l}9.7 \\
8.62\end{array}$ & $\mathrm{t}=3.916(\mathrm{p}<0.001)$ \\
\hline $\begin{array}{l}\text { SP1 }(\mathrm{mg} / \mathrm{l}) \\
\text { Birthweight }>10 \text { th centile } \\
\text { Birthweight } \leqslant 10 \text { th centile }\end{array}$ & $\begin{array}{l}254.8 \\
217.5\end{array}$ & $\begin{array}{l}272.5 \\
250\end{array}$ & $\begin{array}{l}130 \\
105\end{array}$ & $\begin{array}{l}479.5 \\
380\end{array}$ & $t=1.746(N S)$ \\
\hline $\begin{array}{l}\text { PP5 }(\mu \mathrm{g} / \mathrm{l}) \\
\text { Birthweight }>10 \text { th centile } \\
\text { Birthweight } \leqslant 10 \text { th centile }\end{array}$ & $\begin{array}{l}52.3 \\
51.83\end{array}$ & $\begin{array}{l}54 \\
48\end{array}$ & $\begin{array}{l}34 \\
34.8\end{array}$ & $\begin{array}{l}75 \\
80\end{array}$ & $t=0.330(N S)$ \\
\hline
\end{tabular}

NS - not significant. 
present findings confirm numerous previous investigation. Opinion is divided on this subject, observations to the effect that low maternal hPL some workers (including our own group) having levels are associated with intrauterine growth shown an association $[4,7,12,23,25]$, while retardation [13]. Surprisingly, SP1 levels were others have not [8]. A possible explanation lies in not found to be of great value in the present methodological differences. Thus the measurement

Tab. III. Clinical efficiency of circulating levels of hCG, hPL, SP1 and PP5 at 36-40 weeks gestation in the diagnosis of intrauterine growth retardation

\begin{tabular}{llllll}
\hline & hCG & hPL & SP1 & PP5 \\
\hline $\begin{array}{l}\text { Sensitivity } \\
\left(\frac{\mathrm{TP}}{\mathrm{TP}+\mathrm{FN}}\right)^{1}\end{array} \frac{8}{8+46}=14.8 \%$ & $\frac{15}{15+43}=25.86 \%$ & $\frac{8}{8+46}=14.8 \%$ & $\frac{5}{5+49}=9.25 \%$ \\
$\begin{array}{l}\text { Predictive value } \\
\left(\frac{\mathrm{TP}}{\mathrm{TP}+\mathrm{FP}}\right)\end{array} \frac{8}{8+45}=15.09 \%$ & $\frac{15}{15+39}=27.28 \%$ & $\frac{8}{8+45}=15.09 \%$ & $\frac{5}{5+50}=9.09 \%$ \\
Specificity & $\frac{423}{423+45}=90.38 \%$ & $\frac{425}{425+39}=91.59 \%$ & $\frac{423}{423+45}=90.38 \%$ & $\frac{418}{418+50}=89.32 \%$ \\
$\left(\frac{\mathrm{TN}}{\mathrm{TN}+\mathrm{FP}}\right)$ & 0.92 & $15.11(\mathrm{p}<0.001)$ & 0.92 & 0.10 \\
Chi ${ }^{2}$ & $=$ & &
\end{tabular}

${ }^{1} \mathrm{TP}$ - True positive, both maternal serum placental protein levels and infant weight were at or below the 10th centile of the whole population.

TN - True negative, both the maternal serum placental protein levels and infant weight above the 10th centile of the whole population.

FP - False positive, the maternal serum placental protein levels were at or below the 10th centile, but infant weight was above the 10 th centile.

FN - False negative, the maternal serum placental protein levels were above the 10th centile, but infant weight was at or below the 10th centile.

Tab. VI. Circulating levels of hCG, hPL, SP1 and PP5 in relation to the condition of the infant at birth. The probabilities shown were in each case a comparison with subjects with no complications

\begin{tabular}{lcll}
\hline Group & No of subjects & Geometric mean & t-value and probability (P) of difference \\
\hline hCG ( $\mu$ g/l) & & & \\
No fetal distress & 421 & 105.1 & \\
Fetal distress (FD) & 29 & 79.53 & $\mathrm{t}=2.339(\mathrm{P}=0.03)$ \\
Neonatal asphyxia (NNA) & 46 & 122.1 & $\mathrm{t}=1.506$ \\
FD + NNA & 26 & 122.4 & $\mathrm{t}=1.263$ \\
hPL (mg/l) & & & \\
No fetal distress & 421 & 6.834 & $\mathrm{t}=1.982(\mathrm{p}=0.05)$ \\
Fetal distress (FD) & 29 & 6.178 & $\mathrm{t}=0.595$ \\
Neonatal asphyxia (NNA) & 46 & 6.988 & $\mathrm{t}=1.616$ \\
FD + NNA & 26 & 7.236 & \\
SP1 (mg/l) & & & $\mathrm{t}=0.347$ \\
No fetal distress & 421 & 245.8 & $\mathrm{t}=0.595$ \\
Fetal distress (FD) & 29 & 251.7 & $\mathrm{t}=1.616$ \\
Neonatal asphyxia (NNA) & 46 & 275.1 & \\
FD + NNA & 26 & 276.5 & $\mathrm{t}=1.47$ \\
PP5 ( $\mu$ g/l) & & & $\mathrm{t}=1.107$ \\
No fetal distress & 421 & 52.40 & $\mathrm{t}=1.49$ \\
Fetal distress (FD) & 29 & 47.19 & 55.19 \\
Neonatal asphyxia (NNA) & 46 & 57.55 & \\
FD + NNA & 26 & & \\
\hline
\end{tabular}


Tab. V. Sensitivity, predictive value and specificity of a single determination of serum hCG and hPL at $36-40$ weeks gestation in the diagnosis of fetal distress in labor.

\begin{tabular}{|c|c|c|c|c|c|}
\hline & & \multicolumn{2}{|l|}{ hCG } & \multicolumn{2}{|l|}{ hPL } \\
\hline Sensitivity & $\left(\frac{\mathrm{TP}}{\mathrm{TP}+\mathrm{FN}}\right)^{1}$ & $\frac{7}{7+22}$ & $=24.40 \%$ & $\frac{5}{5+24}$ & $=17.24 \%$ \\
\hline Predictive value & $\left(\frac{\mathrm{TP}}{\mathrm{TP}+\mathrm{FP}}\right)$ & $\frac{7}{7+46}$ & $=13.21 \%$ & $\frac{5}{5+50}$ & $=9.09 \%$ \\
\hline Specificity & $\left(\frac{\mathrm{TN}}{\mathrm{TN}+\mathrm{FP}}\right)$ & $\frac{447}{447+}$ & $=90.67 \%$ & $\frac{443}{443+5}$ & $=89.86 \%$ \\
\hline
\end{tabular}

1: See definitions in Tab. III

of hPL is a long-established routine technique in this unit, while that of SP1 continues to be a research procedure for which long-term quality control data is not available. The absence of a useful association between levels of PP5 or hCG and birthweight is less surprising and is in general agreement with previous studies $[15,17,18,24]$. However, levels of hCG were related to the sex of the fetus $[1,2,5,18,19]$ and for a given sex are better related to the delivered weight of the infant [18], though this is not of practical clinical significance.

The relation of hCG and hPL levels to fetal distress is of some potential clinical importance, particularly since the prediction of this complication is not apparently a secondary result of the association with growth retardation. Thus low hCG and hPL appear to predict fetal distress in babies of any weight. This observation indicates that biochemical tests of placental function are not simply a rather inefficient method of 'weighing' the fetus in utero, soon to be replaced by ultrasound, but in fact reflect dynamic aspects of placental function unrelated to the gross morphology of the fetus. This view is reinforced by the fact that hCG levels, which are much less efficient than hPL in the detection of IUGR, are more closely associated than hPL with fetal distress (Tab. IV).

\section{Summary}

The purpose of this study was to compare the clinical usefulness of four placental proteins (hCG, hPL, SP1 and PP5) in the prediction of fetal status at delivery. Single blood samples were then taken from 527 unselected women with singleton pregnancy between 36-40 weeks gestation. The group included 27 patients with preeclampsia, 7 with antepartum hemorrhage and 5 who delivered a stillborn child; the latter were excluded from the overall analysis. The measurement of serum hCG, hPL, SP1 and PP5 was performed by radioimmunoassay. The results were analysed by calculation of means and standard deviations after logarithmic transformation for the comparison of sub-populations. The median levels of hCG, hPL, SP1 and PP5 were found to be stable between 36 and 40 weeks. There was no difference in the levels of hCG, hPL, SP1 and PP5 in patients with pre-eclampsia when compared to the whole population. Only hPL showed a significant association with growth retardation. Both hCG and hPL were significantly decreased in sub- jects whose infants developed fetal distress during labor. The mean birthweight in the fetal distress group alone $(3273 \mathrm{~g})$ did not differ from that of the population as a whole (3303 g).

This is the first study in which maternal serum hCG, hPL, SP1 and PP5 have been examined in the same obstetric population in late pregnancy. We demonstrated a clear association between low maternal hPL levels and the occurrence of intrauterine growth retardation, in agreement with previous published reports. SP1 levels were not related to intrauterine growth retardation. The absence of a useful association between PP5 or hCG and birthweight is less surprising and is in general agreement with previous studies. Low levels of hCG and hPL were associated with the occurrence of fetal distress in labor; the association was independent of delivered weight. This suggests that these proteins reflect both the overall growth of the child and dynamic aspects of fetal nutrition.

Keywords: Fetal distress in labor, intrauterine growth retardation, placental proteins (hCG, hPL, SP1, PP5). 


\section{Zusammenfassung}

Vergleichende Untersuchungen zur klinischen Verwertbarkeit von 4 Plazentaproteinen im letzten Schwangerschaftstrimester

Wir haben in dieser Untersuchung die Aussagekraft von 4 Plazentaproteinen (HCG, HPL, $\mathrm{SP}_{1}$ und $\mathrm{PP}_{5}$ ) beziglich des fetalen Zustands zum Zeitpunkt der Geburt miteinander verglichen. Dazu wurden Blutproben von 527 zufällig ausgewählten Frauen mit Einzelschwangerschaften zwischen der 36. und 40. Woche entnommen. In der Gruppe waren 27 Patientinnen mit Präeklampsie, 7 mit Blutungen in der Schwangerschaft und 5 Frauen mit einer Totgeburt; letztere wurden in der Auswertung nicht berücksichtigt. Die Serumkonzentrationen von $\mathrm{HCG}, \mathrm{HPL}, \mathrm{SP}_{1}$ und $\mathrm{PP}_{5}$ wurden mit Hilfe der RIA-Methode bestimmt. Wir berechneten Mittelwerte und Standardabweichungen nach logarithmischer Transformation zwecks Vergleich der Untergruppen. Die mittleren Konzentrationen von HCG, HPL, $\mathrm{SP}_{1}$ und $\mathrm{PP}_{5}$ waren zwischen der 36. und 40. Schwangerschaftswoche stabil. Ein Vergleich der HCG-, HPL-, SP und $\mathrm{PP}_{5}$-Werte $\mathrm{zwischen} \mathrm{der} \mathrm{Präeklampsie-Gruppe} \mathrm{und}$ dem Gesamtkollektiv ergab keinen Unterschied. Nur der HPL-Spiegel zeigte einen signifikanten Zusammenhang mit einer Wachstumsretardierung. Sowohl HCG wie auch
HPL waren bei den Patientinnen, deren Kinder unter der Geburt ein fetales Distress-Syndrom entwickelten, signifikant erniedrigt. Das mittlere Geburtsgewicht in der Distress-Gruppe $(3273 \mathrm{~g})$ zeigte keine deutliche Abweichung von dem des Gesamtkollektivs (3303 g).

In der vorliegenden Untersuchung wurden zum ersten Mal die mütterlichen Serumkonzentrationen von HCG, HPL, $\mathrm{SP}_{1}$ und $\mathrm{PP}_{5}$ im gleichen geburtshilflichen Kollektiv in der Spätschwangerschaft gemessen. In Übereinstimmung mit früheren Arbeiten konnten wir einen deutlichen Zusammenhang zwischen niedrigen HPL-Spiegeln und intrauteriner Wachstumsretardierung feststellen. $\mathbf{S P}_{\mathbf{1}^{-}}$Konzentrationen ließen keine Beziehung zu intrauteriner Wachstumsverzögerung erkennen. Weniger überraschend und ebenfalls in Übereinstimmung mit früheren Veröffentlichungen ist dagegen der fehlende Zusammenhang zwischen PP $_{5}$ - sowie HCG-Spiegeln und dem Geburtsgewicht. Niedrige HCG- und HPL-Werte korrelierten mit dem Auftreten von fetalem Distress unter der Geburt, wobei dieser Zusammenhang unabhängig vom Geburtsgewicht war. Wir glauben, daß diese Proteine das gesamte fetale Wachstum wie auch dynamische Aspekte fetaler Ernährung widerspiegeln.

Schlüsselwörter: Fetales Distress-Syndrom unter der Geburt, intrauterine Wachstumsretardierung, Plazentaproteine (HCG, HPL, $\mathrm{SP}_{1}, \mathrm{PP}_{5}$ ).

\section{Résumé}

Une étude comparative de l'utilisation clinique de 4 protéines placentaires au cours du troisième trimèstre Le but de cette étude est de comparer l'utilité clinique de 4 protéines placentaires (HCG, HPL, SP1 et PP5) pour la prévision de l'état foetal à l'accouchement. Des échantillons de sang ont été prélevés chez 521 femmes non sélectionnées ayant une grossesse unique entre 36 et 40 semaines. Ce groupe inclut 27 patientes prééclamptiques, 7 hémorragies de la grossesse, et 5 mortsnés, ces derniers ont été exclus de l'analyse globale. La mesure de HCG, HPL, SP1 et PP5 a été réalisée par radioimmunologie. Les résultâts ont été analysés par le calcul des déviations moyennes et standard après transformation logarithmique pour la comparaison de sous-populations. Les taux moyens de HCG, HPL, SP1 et PP5 ont été trouvés stables entre 36 et 40 semaines. Il n'y a pas de différences dans les taux d'HCG, HPL, SP1 et PP5 chez les patientes pré-éclamptiques en comparaison de la population d'ensemble. Seul HPL montre une association significative avec le retard de croissance. Et HCG et HPL sont diminués de façon significative chez les sujets dont les enfants ont développé une souffrance foetale en cours de travail. Le poids de naissance moyen dans le groupe isolé des souffrances foetales $(3273 \mathrm{~g})$ ne diffère pas de celui de la population globale $(3303 \mathrm{~g})$.

Il s'agit de la première étude dans laquelle HCG, HPL, SP1 et PP5 sériques maternels ont été dosés dans la même population en fin de grossesse. Les auteurs ont démontré une association évidente entre des taux d'HPL maternels bas et la survenue d'un retard de croissance intra-utérin ce qui est en accord avec les travaux publiés auparavant. Les taux de SP1 ne sont pas liés au retard de croissance. L'absence de liaison utilisable entre PP5 ou HCG et le poids de naissance est moins étonnante et est en accord global avec les études antérieures; des taux bas d'HCG et d'HPL sont associés avec la survenue d'une souffrance foetale en cours de travail; la liaison est indépendante du poids de naissance. Cela suggère que ces protéines sont le reflet à la fois de la croissance dans son ensemble de l'enfant et à la fois des aspects dynamiques de la nutrition foetale.

Mots-clés: Protéines placentaires (HCG, HPL, SP1, PP5), retard de croissance intra-utérin, souffrance foetale en cours de travail. 
Bibliography

[1] BORODITSKY, R. S., F. I. REYES, J. S. WINTER, C. F. FAIRMAN: Serum human chorionic gonadotrophin and progesterone patterns in the last trimester of pregnancy: Relationship to fetal sex. Amer. J. Obstet. Gynec. 121 (1975) 238

[2] BRODY, S. G., G. CARLSTROM: Human chorionic gonadotrophin pattern in serum and its relation to the sex of the fetus. J. Clin. Endocr. Metab. 25 (1965) 792

[3] CHARD, T.: Placental Function. In: STALLWORTHY, J., G. L. BOURNE (eds): Recent advances in obstetrics and gynaecology. Churchill Livingstone, Edinburgh 1977

[4] ChAPMAN, M., W. R. JONES: Pregnancy-specific beta-1 glycoprotein (SP1) in normal and abnormal pregnancy. Aust. N.Z. J. Obstet. Gynaecol. 18 (1978) 172

[5] CROSIGNANI, P. G., T. NENCIONI, B. BRAMBATI: Concentration of chorionic gonadotrophin and chorionic somatomammotrophin in maternal serum, amniotic fluid and cord blood at term. J. Obstet. Gynaec. Brit. Cwlth. 79 (1972) 122

[6] CROWTHER, M., J. G. GRUDZINSKAS, T. POULTON, Y.B. GORDON: Trophoblastic proteins in ovarian carcinoma. Obstet. Gynecol. 53 (1979) 59

[7] GORDON, Y. B., J. G. GRUDZINSKAS, D. JEFFREY, T. CHARD, A. T. LETCHWORTH: Concentrations of pregnancy specific $\beta_{1}$ glycoprotein in maternal blood in normal pregnancy and in intrauterine growth retardation. Lancet, I (1977) 331

[8] HUGHes, G., P. BISCHOF, G. WILSON, A. KLOPPER: Assay of a placental protein to determine fetal risk. Brit. Med. J. 280 (1980) 671

[9] KLOPPER, A. (ed): In: Plasma hormone assay in evaluation of fetal wellbeing. Churchill Livingstone, Edinburgh 1976

[10] KLOPPER, A., T. CHARD (eds): In: Placental proteins. Springer, Berlin-Heidelberg-New York 1979

[11] LEE, J. N., H. T. SALEM, S. C. HUANG, P. C. OUYANG, M. SEPPALA, T. CHARD: Placental protein 5 (PP5) in severe pre-clampsia and eclampsia. Int. J. Gynaecol. Obstet. 19 (1981) 65

[12] LETCHWORTH, A. T., R. J. BOARDMAN, C. BRISTOW, J. LANDON, T. CHARD: Rapid semiautomated method for the measurement of human chorionic somatomammotrophin. The normal range in the third trimester and its relation to fetal weight. J. Obstet. Gyneac. Brit. Cwlth. 78 (1971) 542

[13] LETCHWORTH, A. T.: Human placental lactogen assay as a guide to fetal wellbeing. In: KLOPPER A. (ed.): Plasma hormone assay in evaluation of fetal wellbeing. Churchill Livingstone, Edinburgh 1976

[14] LIN, T. M., S. P. HALbERT, D. KIEFER: Pregnancy-associated plasma proteins during human gestation. J. Clin. Invest. 54 (1974) 576

[15] NISBETT, A. D., R. D. BREMNER, V. JANDIAL, H. W. SUTHERLAND, C. H. W. HORNE: Placental protein 5 (PP5) in complicated pregnancies. Brit. J. Obstet. Gynaec. 88 (1981) 492
[16] OBIEKWE, B. C., DIÁNA PENDLEBURY, Y. B. GORDON, J. G. GRUDZINSKAS, T. CHARD, H. BOHN: The radioimmunoassay of placental protein 5 and circulating levels in maternal blood in the third trimester of normal pregnancy. Clin. Chim. Acta 95 (1979) 509

[17] OBIE KWE, B. C., J. G. GRUDZINSSKAS, T. CHARD: Circulating levels of placental protein 5 in the mother: Relation to birth weight. Brit. J. Obstet. Gynaec. 87 (1980) 302

[18] OBIEKWE, B. C., T. CHARD: Human chorionic gonadotrophin levels in maternal blood in late pregnancy: Relation to delivered weight, sex and condition of the infant at birth. Brit. J. Obstet. Gynaec. (in press) (1982)

[19] PENNY, R., N. O. AlAMBIWONNU, S. B. FRASIER: Follicle stimulating hormone (FSH) and luteinising hormone-human chorionic gonadotrophin (LH-hCG) concentration in paired maternal and cord sera. Paediatrics 53 (1974) 41

[20] SAlEM, H. T., B. C. OBIEKWE, A. T. M. AL-ANI, M. SEPPALA, T. CHARD: Molecular heterogeneity of placental protein 5 (PP5) in late pregnancy serum and plasma: Evidence for a heparin-PP5 polymer. Clin. Chim. Acta 107 (1980) 211

[21] SALEM, H. T., J. G. WESTERGAARD, P. HINDERSSON, M. SEPPALA, T. CHARD: Placental protein 5 (PP5) in placental abruption. Brit. J. Obstet. Gynaec. 88 (1981) 500

[22] SALEM, H. T., J. N. LEE, M. SEPPALA, L. VAARA, P. AULA, A. T. M. AL-ANI, T. CHARD: Measurement of placental protein 5, placental lactogen and pregnancy specific $\beta_{1}$ glycoprotein in mid-trimester as a predictor of outcome of pregnancy. Brit. $J$. Obstet. Gynaec. 88 (1981) 371

[23] SORENSEN, S.: An electroimmunoassay of the pregnancy-specific beta 1-glycoprotein (SP1) in normal and pathological pregnancies, and its clinical value compared to human chorionic-mammotropin (hCS). Acta Obstet. Gynecol. Scand. 57 (1978) 193

[24] SPELLACY, W. N., P. W. CONLY, W. W. ClEVELAND, W. C. BUHI: Effects of fetal sex and weight and placental weight on maternal serum progesterone and chorionic gonadotrophin concentration. Amer. J. Obstet. Gynec. 122 (1975) 278

[25] TATRA, G., G. BREITENECKER, W. GRUBER: Serum concentration of pregnancy-specific beta 1-glycoprotein (SP1) in normal and pathological pregnancy. Arch. Gynäkol. 217 (1974) 383

[26] TOWLER, C. M., C. H. W. HORNE, V. JANDIAL, D. M. CAMPBELL, I. MACGILlivRAY: Plasma levels of pregnancy specific beta-1 glycoprotein in complicated pregnancies. Brit. J. Obstet. Gynaec. 84 (1977) 258

Received August 24, 1982. Accepted November 30,1982.

B. C. Obiekwe, M. D.

St. Bartholomew's Hospital Dept. of Reprod. Physiology 51-53 Bartholomew Close West Smithifield London ECIA 7BE/ENGLAND 